\title{
ІНДИВІДУАЛЬНА БЕСІДА ЯК ІНСТРУМЕНТ ПОКРАЩЕННЯ ОПАНУВАННЯ НАВЧАЛЬНОГО МАТЕРІАЛУ
}

\author{
T. M. Muratova, V. V. Dobrovolskyi \\ Odesa National Medical University \\ INDIVIDUAL CONVERSATION, AS A TOOL FOR IMPROVING \\ THE STUDYING OF EDUCATIONAL MATERIAL
}

\begin{abstract}
Мета роботи - розглянути питання щодо використання індивідуальної бесіди як інструменту поглибленого вивчення матеріалу і підготовки майбутніх фахівців неврологів.

Основна частина. Бесіда - це така форма спілкування, яка застосовується з метою обміну думками, інформацією. Бесіда використовується перш за все як інструмент спільного пошуку оптимального вирішення проблем. Розуміючи, що кожна з бесід не має загальних рецептів, які б забезпечували її високу ефективність в усіх випадках, викладач повинен творчо підходити до спілкування зі студентом. Виходячи з професійної спрямованості, викладачі кафедри ведуть педагогічні бесіди, коли це потрібно, але намагаються останнім часом навчити, підготувати студентів до ведення медичної бесіди лікаря з пацієнтом, яка знадобиться в майбутньому. Лікар-невролог у спілкуванні з пацієнтом, крім лише медичних проблем, повинен багато уваги приділяти вивченню питань, пов'язаних із соціальним середовищем, національними особливостями, ретельно розібратися зі способом життя, умовами проживання та праці, особливостями харчування, наявними спадковими хворобами близьких родичів. Лікар віч-на-віч спілкується з пацієнтом, що сприяє: встановленню контакту, довіри і взаєморозуміння, виникненню спільних поглядів на тактику лікування для досягнення мети - одужання. Лікар і пацієнт стають однодумцями, і лише в такому випадку вони зможуть спільно боротися з хворобою та отримати перемогу над нею. Основні етапи бесіди - це підготовка, встановлення контакту, орієнтація в ситуації обговорення, питання й прийняття спільного рішення, і що особливо важливо для лікаря, вихід з контакту. Дуже важливо завоювати довіру у студента, яка дозволяє в процесі спілкування компенсувати слабкість аргументів та доказів. Дуже важливо тому, що студенти з повагою ставляться до суджень такого викладача, який вміє завоювати авторитет високим професіоналізмом, вмінням заохотити до вивчення предмета, тактом, зовнішністю, інтелектом, вміло поставленою мовою. Дуже важливо використовувати авторитет викладача, який він здобув попередньою роботою зі студентами на кафедрі в університеті та лікарській діяльності.

Висновки. Індивідуальна бесіда є дійовою формою взаємодії, яку використовують педагоги під час спілкування зі студентами. Це найчастіше бесіди особливого характеру. Зокрема вирішуються ті завдання, які може поставити собі викладач. І в першу чергу це прищеплення любові до предмета “Неврологія” через індивідуальні досягнення викладача, колективні досягнення в науці й охороні здоров’я (лікувальній справі) колективу кафедри, університету, країни. Педагогу в таких бесідах хочеться, як старшому, вплинути на студента, стимулювати його до поведінки за готовим рецептом. Але практично всі люди не хочуть бути об’єктом виховання. Більшості з них потрібні увага і повага. Педагог повинен цікавитися життям студентів. На довіру молодь найчастіше відповідає довірою. Від студента не слід вимагати нереального, того, що він не зможе на даному етапі зробити. Пропозиції, думки педагога повинні бути конструктивними. Бажано не нав’язувати студенту своїх порад, а оцінку його висновкам давати лише в крайніх випадках. Розмову слід вести так, щоб студент сам або зробив потрібний висновок, або попросив педагога поради, як діяти в подібній ситуації.
\end{abstract}

Ключові слова: педагогіка; неврологія; бесіда; викладання неврології.

The aim of the work - to use individual conversations as a tool for in-depth study of the material and the training of future neurologists.

The main body. A conversation is a form of communication that is used to exchange thoughts and information. The conversation is primarily used as a tool for jointly finding optimal problem solving. Understanding that each of the conversations does not have common recipes that would ensure its high efficiency in all cases, the teacher must creatively approach communication with the student. Based on the professional orientation, the teachers of the department conduct pedagogical conversations when needed, but they are trying to teach in recent years, prepare students for a doctor's medical conversation with the patient, which will be needed in the future. The neurologist in communicating with the patient in addition to medical problems should pay a lot of attention to the study of issues related to the social environment, national peculiarities, to carefully consider the way of life, living conditions and work, the peculiarities of nutrition, the existing hereditary diseases of close relatives. A face-to-face communication with the patient helps: the establishment of contact, trust and understanding, and the emergence of common views on treatment tactics to achieve the goal of recovery. The doctor and patient become like-minded, and only in this case they can jointly fight the disease and gain victory over it. The main stages of a conversation are preparation, establishing contact, orientation in a situation of discussion, a question and a joint decision, and that is especially important for a doctor, getting out of contact. It is very important to gain confidence in the student, which allows in the

() Т. М. Муратова, В. В. Добровольський 
course of communication to compensate for the weakness of arguments and evidence. It is very important that the students respect the judgments of such a teacher who can gain authority with high professionalism, the ability to encourage the study of the subject, tact, appearance, intelligence, skillfully set language. It is very important to use the authority of the teacher, which he received from previous work with students at the department at the university and medical activities.

Conclusions. An individual conversation is an effective form of interaction that teachers use when communicating with students. This is most often a conversation of a special nature. In particular, those tasks that can be put in place by a teacher are solved. And first and foremost, this is a grafting of love for the subject of neurology through the individual achievements of the teacher, collective achievements in science and health care (medical) of the staff of the department, university, and country. In such conversations, the teacher wants to, as a senior, influence the student, stomp his behavior towards a ready-made recipe. But practically all people do not want to be the object of education. Most of them need attention and respect. The teacher should be interested in the life of students. Most often young people response to trust is trust. The student should not demand unrealistic, that he can not make proposals at this stage, the teacher's thoughts should be constructive. It is advisable not to impose a student on his advice, but to evaluate his conclusions only in extreme cases. The conversation should be conducted so that the student himself either made the desired conclusion, or asked the teacher to advise how to act in such situations.

Key words: pedagogy; neurology; conversation; neurology teaching.

Вступ. Процес викладання матеріалу на кафедрі неврології Одеського національного медичного університету має свої особливості, які впливають на якість його засвоювання.

Порівняно невелика кількість навчального часу не повною мірою дає можливість привернути увагу студентів до вивчення предмета, прищепити необхідність у майбутньому стати фахівцем у цьому важливому напрямку медицини.

Викладач на кафедрі не завжди встигає протягом циклу неврології (15 днів) прищепити любов до предмета, виявити здібності студента. Саме тому така невелика кількість майбутніх лікарів вибирає неврологію своїм фахом.

Не вистачає часу знайти індивідуальний підхід до кожного студента, який у майбутньому може стати фахівцем неврологом, що зменшує рівень засвоювання матеріалу.

Іноді конкретному спілкуванню заважають незнання менталітету та національних особливостей, різний рівень культури та загальної підготовки іноземних студентів.

Неповне завершення реформи медичного обслуговування населення, невизначеність в її завершенні заважає студентам обрати майбутній напрямок своєї діяльності. Тому викладачі кафедри більше приділяють уваги студентам, які в майбутньому планують стати фахівцями неврологами.

Всі ці особливості вимагають від викладачів кафедри для засвоювання матеріалу на більш високому рівні інтенсивно спілкуватися зі студентами, повною мірою використовувати індивідуальні бесіди як інструмент поглибленого вивчення матеріалу і підготовки майбутніх фахівців неврологів.

Мета роботи - розглянути питання щодо використання індивідуальної бесіди як інструменту поглибленого вивчення матеріалу і підготовки майбутніх фахівців неврологів.
Основна частина. Незважаючи на обмеженість часу, викладачі кафедри використовують індивідуальні бесіди, які мають навчальну спрямованість, коли студенти працюють самостійно. Іноді бесіди мають особистий характер [1].

Для успішного проведення бесіди потрібен високий рівень культури спілкування, знання соціальної психології та національного менталітету студента.

Бесіда - це така форма спілкування, яка застосовується з метою обміну думками, інформацією. Бесіда використовується перш за все як інструмент спільного пошуку оптимального вирішення проблем. Розуміючи, що кожна з бесід не має загальних рецептів, які б забезпечували ї̈ високу ефективність в усіх випадках, викладач повинен творчо підходити до спілкування зі студентом [2].

Виходячи з професійної спрямованості, викладачі кафедри ведуть педагогічні бесіди, коли це потрібно, але намагаються останнім часом навчити, підготувати студентів до ведення медичної бесіди лікаря з пацієнтом, яка знадобиться в майбутньому. Такий висновок зроблено на основі власного досвіду співробітників кафедри, він дає новий підхід у практиці лікаря-невролога, яка має цілу низку особливостей.

Лікар-невролог у спілкуванні з пацієнтом, крім лише медичних проблем, повинен багато уваги приділяти вивченню питань, пов’язаних із соціальним середовищем, національними особливостями, ретельно розібратися зі способом життя, умовами проживання та праці, особливостями харчування, наявними спадковими хворобами близьких родичів. Результатом обстеження має бути план лікування, який не лише включає в себе перелік фармацевтичних препаратів, а й практичні рекомендації щодо зміни способу життя, якщо це необхідно. Лікар віч-на-віч спілкується з пацієнтом, що сприяє: встановленню контакту, довіри і взаєморозуміння, 
виникненню спільних поглядів на тактику лікування для досягнення мети - одужання. Лікар і пацієнт стають однодумцями, і лише в такому випадку вони зможуть спільно боротися з хворобою та отримати перемогу над нею.

Основні етапи бесіди - це підготовка, встановлення контакту, орієнтація в ситуації обговорення, питання й прийняття спільного рішення, і що особливо важливо для лікаря, вихід з контакту. Пацієнту дуже важливо знати, що він в будь-який час може звернутися до лікаря і той не відмовить йому в пораді, завжди приділить час і увагу. Доброзичливість, можливість вселити оптимізм у боротьбі з хворобою приносить користь у цій нелегкій праці, особливо пацієнтам із захворюванням нервової системи.

Важливу увагу приділяємо підготовці до бесіди, яка вимагає:

- підібрати найбільш доречний момент;

- в деканаті вияснити відомості про студента, особливо викладача турбує його ставлення до предмета, до викладача, мету його навчання в медичному університеті та перспективи подальшого поглибленого вивчення предмета “Неврологія”;

- для бесіди з іноземними студентами необхідно розібратися з національними особливостями, менталітетом та станом медицини в конкретній країні;

- уявити собі негативну позицію студента, передбачити або розвинути зацікавленість предметом. Продумати методику переконання студента і заохочення до вивчення неврології;

- дуже важливо вміло закінчити бесіду, незважаючи на негативний результат, або непорозуміння, не показувати розчарування, якщо студент не виявив зацікавлення до навчання. Взяти на облік тих, хто виявив ініціативу до більш поглибленого навчання неврології.

Встановити контакт дуже важливо в процесі бесіди. Психологічний контакт - це духовний зв'язок, який забезпечує можливість взаєморозуміння й взаємовпливу.

Дуже важливо завоювати довіру у студента, яка дозволяє в процесі спілкування компенсувати слабкість аргументів та доказів. На зміцнення довіри до викладача впливає багато факторів у короткий час перебування студентів на кафедрі. Дуже важливо тому, що студенти з повагою ставляться до суджень такого викладача, який вміє завоювати авторитет високим професіоналізмом, вмінням заохотити до вивчення предмета, тактом, зовнішністю, інтелектом, вміло поставленою мовою. Знання історичних процесів в Україні, а також країн, звідки прибули студенти. Дуже важливо використовувати авторитет викладача, який він здобув попередньою роботою зі студентами на кафедрі в університеті та лікарській діяльності. На допомогу приходить якісна наочність у кабінетах кафедри. Авторитету викладача сприяє позитивний матеріал у засобах масової інформації, в тому числі й на шпальтах газет нашого університету: “Пульс" та “Його величність пацієнт”.

У такому випадку більшість думок викладача студент сприймає на віру, що дуже важливо в обмеженні часом.

Про доброзичливість викладача свідчить легка усмішка, нахил корпусу, голови в бік студента, зацікавленість у виразі очей. Далі слід привітатися і зробити паузу. Вона необхідна для того, щоб студент мав можливість підключитися до розмови. Якщо цього не зробити, то діалог може не реалізуватися. Дуже важливо вже при першій зустрічі запам’ ятати ім'я та прізвище співрозмовника.

Культурна людина займе таке положення при спілкуванні, яке буде свідчити про повагу до студента. Ми рекомендуємо 1-1,5 м. При цьому слід враховувати особливості національного менталітету. Наприклад, що стосується іноземних студентів чоловіків арабського світу, то дистанцію треба скоротити, а при бесіді з представниками жіночої статі з цього регіону слід запросити бути присутнім старосту групи.

На початку бесіди доцільно поговорити про те, що об’єднує співрозмовників, відшукати спільні інтереси. Доцільно поговорити про студента, про його країну, лише потім про мету розмови. Тон бесіди повинен бути привітним, доброзичливим, що допоможе повірити в щирість викладача.

Наступний етап бесіди - орієнтація в умовах розмови та особливостях студента. Це передбачає вивчення особливостей зовнішнього середовища та врахування емоційного стану. Для того щоб не вирували емоції, можливо, пожартувати, попросити допомоги в простій справі, звернути увагу на важливу для нього проблему, яка вимагає активного мислення, поставити питання на нейтральну тему. Це частина того, що можливо зробити. Кожна ситуація вимагає чуйності, оперативності, творчості.

Треба мати уявлення про особливості студента: індивідуальні, вікові та статеві. На результат бесіди накладає серйозний відбиток темперамент, який треба розпізнати та враховувати.

Важливо враховувати стать співрозмовника. Для чоловіків характерною є тенденція більш глобаль- 
но, широко дивитися на проблему, жінки краще сприймають деталі, окремі нюанси.

Таким чином, орієнтація в індивідуальній бесіді слугує відображенню та регуляції взаємодії, дає можливість отримати інформацію про ситуацію. На цьому плануються стратегія і тактика розмови.

На етапі обговорення та прийняття рішення важливе вміння слухати співрозмовника та обгрунтувати свою позицію.

Доцільно звернути увагу на деякі поради:

- уважно слухати і чути;

- намагатися перейти до діалогу;

- дати можливість студенту спокійно висловити свою думку;

- свою інформацію викласти добре та послідовно;

- вибрати способи та засоби аргументування залежно від індивідуальних і національних особливостей студента (інтелекту, віку, статі, типу темпераменту тощо).

Приймаючи рішення, доцільно керуватися рекомендаціями:

- визначити момент для закінчення бесіди;

- сформувати мету та продумати альтернативні варіанти рішення;

- намагатися досягти добровільної згоди;

- не виявляти розгубленості, невпевненості наприкінці бесіди, навіть у випадку, якщо мета не досягнута;

- в кінці бесіди використати найсильніший свій аргумент.

При виході з контакту доцільно виявити надію на подальше співробітництво, дотримуючись правил етикету.

Висновки. Індивідуальна бесіда $є$ дійовою формою взаємодії, яку використовують педагоги під час спілкування зі студентами. Це найчастіше бесіди особливого характеру. Нерідко проводяться також бесіди навчальної спрямованості, особливо коли студенти працюють самостійно.

Таким чином, бесіда приводить до покращення якості засвоювання навчального матеріалу та сприяє майбутньому вибору спеціалізації молодого лікаря.

Зокрема, вирішуються ті завдання, які може поставити собі викладач. I в першу чергу, це прищеплення любові до предмета “Неврологія” через індивідуальні досягнення викладача, колективні досягнення в науці й охороні здоров’я (лікувальній справі) колективу кафедри, університету, країни.

Для їх успішного проведення особливо потрібні високий рівень культури спілкування, знання психології, національного менталітету студента.

Педагогу в таких бесідах хочеться, як старшому, вплинути на студента, стимулювати його до поведінки за готовим рецептом. Але практично всі люди не хочуть бути об’ єктом виховання. Більшості з них потрібні увага і повага.

Педагог проводить індивідуальну бесіду зі студентом у різних умовах. Частіше в кабінеті чи аудиторії, під час перерви тощо. Головне, щоб не було формалізму, нотацій, менторства, залякування.

Перш за все, зустрівшись зі студентом, бажано поговорити з ним про його інтереси, успіхи, гарні вчинки тощо. Такий початок сприяє встановленню контакту в бесіді. Педагог повинен цікавитися життям студентів. На довіру молодь найчастіше відповідає довірою.

Далі в розмові бажано перейти до обговорювання конкретного факту, який викликає занепокоєння.

Від студента не слід вимагати нереального, того, що він не зможе на даному етапі зробити. Пропозиції, думки педагога повинні бути конструктивними, особливо коли це стосується спеціалізації.

Бажано не нав'язувати студенту своїх порад, а оцінку його висновкам давати лише в крайніх випадках. Розмову слід вести так, щоб студент сам або зробив потрібний висновок, або попросив педагога поради, як діяти в подібних ситуаціях. 3окрема, це стосується вибору майбутньої спеціалізації студента.

Важливо закінчити бесіду на оптимістичній ноті, висловити свою віру в студента, в його особистість, разом намітити перспективу його дій. Якщо можливо в окремих випадках, допомогти студенту в майбутньому, якщо студент вирішив вивчати більш поглиблено неврологію.

Таким чином, можна сказати, що бесіди різних видів $є$ ефективною формою для встановлення взаємодії та взаєморозуміння між педагогом і студентом. Успішне їх використання підвищує культуру спілкування на кафедрі, слугує підвищенню якості засвоювання матеріалу, створенню позитивного настрою, атмосфери довіри та доброзичливості, що впливає на якість навчального процесу і вибір майбутньої спеціалізації за результатами навчання студентів. 


\section{Список літератури}

1. Зельдович Б. З. Деловое общение : учебное пособие / Б. 3. Зельдович. - М. : Издательство “Альфа-пресс”, 2007. - 456 с.

\section{References}

1. Zeldovich, B.Z. (2007). Delovoye obshcheniye: uchebnoye posobiye [Business communication: a tutorial]. Moscow: Izdatelstvo: «Alfa-press» [in Russian].

Електронна адреса для листування: dr_dobrovol@ukr.net
2. Столяренко Л. Д. Психология делового общения и управления : учебник / Л. Д. Столяренко. - Ростов на Дону : Феникс, 2005. - 416 с.

2. Stolyarenko, L.D. (2005). Psikhologiya delovogo obshcheniya i upravleniya Uchebnik [The psychology of business communication and management. Textbook]. Rostov na Donu: «Feniks» [in Russian]. 